\title{
Importance of dynamic managerial capabilities on the performance of small family businesses
}

\author{
La importancia de las capacidades dinámicas gerenciales \\ en el desempeño de las pequeñas empresas familiares \\ Salvador Samuel Guajardo Treviño ${ }^{1 *}$ \\ Laura Esther Zapata Cantú ${ }^{2}$ \\ ${ }^{1}$ Universidad de Monterrey, México \\ ${ }^{2}$ Instituto Tecnológico y de Estudios Superiores de Monterrey, México
}

Received July 23, 2018; accepted July 2, 2019

Available online July 29, 2019

\begin{abstract}
This research aims to determine how an entrepreneurial chief executive officer's (ECEO) level of dynamic managerial capabilities (DMCs) influences the performance of small family firms, as well as family firm governance structure moderates this relationship. Additionally, this paper offers insights into one antecedent of ECEOs' DMCs, namely managerial human capital. A total of 213 observations were obtained from ECEOs who have founded and operate a minimum of one small family firm in Mexico. After testing the hypotheses using a structural equation model, a positive relationship was found between the level of an ECEO's DMC and family firm performance. It was further observed that family governance structure in the firm could positively moderate ECEO DMCs's effect on firm performance, where family governance structure was calculated as the number of family members that work in the
\end{abstract}

\footnotetext{
*Corresponding author.

E-mail address: salvador.guajardot@udem.edu (S.S. Guajardo Treviño).

Peer Review under the responsibility of Universidad Nacional Autónoma de México.

http://dx.doi.org/10.22201/fca.24488410e.2020.2132

0186- 1042/@2019 Universidad Nacional Autónoma de México, Facultad de Contaduría y Administración. This is an open access article under the CC BY-NC-SA (https://creativecommons.org/licenses/by-nc-sa/4.0/)
} 
family firm independently, formally, or informally, as well as whether they work full-time or part-time. Overall, the results indicate that in small family firms, the ability to change and adapt to create a sustainable competitive advantage depends, to some degree, on certain types of individual capabilities (DMCs), rather than simply on organizational capabilities, known as dynamic capabilities (DCs).

JEL Code: L25, L26, M13

Keywords: Entrepreneurial chief executive officer; Dynamic managerial capacities; Models of structural equations; Small family businesses

\section{Resumen}

Esta investigación tiene como objetivo determinar cómo el nivel de capacidades dinámicas gerenciales (DMC) de un director general emprendedor (ECEO) influye en el rendimiento de las pequeñas empresas familiares, y cómo la participación de la familia modera esta relación. Además, este documento ofrece información sobre un antecedente de las DMC de los ECEOs, a saber, el capital humano gerencial. Se obtuvieron un total de 213 observaciones de los ECEO que han fundado y han operado al menos una pequeña empresa familiar en México. Después de probar las hipótesis utilizando un modelo de ecuaciones estructurales, se encontró una relación positiva entre el nivel del DMC del ECEO y el desempeño de la empresa familiar. Se observó además que la participación de la familia en la empresa podría moderar positivamente el efecto de los DMC sobre el desempeño empresarial, donde la participación familiar se calculó como el número de miembros de la familia que trabajan en la empresa familiar de manera independiente, formal o informal, y si trabajan por completo tiempo o a tiempo parcial. En general, los resultados indican que en las pequeñas empresas familiares, la capacidad de cambiar y adaptarse para crear una ventaja competitiva sostenible depende, hasta cierto punto, de ciertos tipos de capacidades individuales (DMC), más que simplemente de capacidades organizacionales, conocidas como capacidades dinámicas (DC).

Código JEL: L25, L26, M13

Palabras clave: Director general emprendedor; Capacidades dinámicas gerenciales; Modelos de ecuaciones estructurales; Pequeñas empresas familiares

\section{Introduction}

Today's fast paced-world forces firms to adapt fast to environmental changes. Such adaptation behaviors can include, among others, doing nothing and ignoring the situation, ad-hoc problem solving, trial and error efforts, and developing dynamic capabilities (Teece, 2007; Teece, 2018; Winter, 2003;). 
There are well-documented cases where the use of dynamic capabilities $\left(\mathrm{DCs}^{1}\right)$ has resulted in positive firm-level outcomes. One of such examples is IBM's impressive transformation in the 1990s, which saw the firm successfully shift its core business from hardware manufacturing to providing services and software. In 1993, these latter divisions roughly represented 27 percent of the firm's revenues, but by 2001, they represented 58 percent (Harreld et al., 2007). Samsung Electronics' transformation in the semiconductor industry is another case where use of developed dynamic capabilities (DCs) contributed to firm survival and success (Lee and Slater, 2007).

In contrast to the IBM and Samsung Electronics cases, Smith Corona, once the world's leading typewriter manufacturer, collapsed by the mid-1980s due to rapid and pronounced market dissipation of their main products and despite its efforts to exercise all available DCs (Danneels, 2011). In this case, DCs only served to delay for some years the firm's unavoidable and imminent financial bankruptcy.

These three cases demonstrate how DCs are necessary but not sufficient alone to achieve superior performance; furthermore, simply applying DCs will not always enable successful organizational adaptation (Eisenhardt and Martin, 2000; Ferreira et al., 2019; Leih, and Teece, 2016; Miles et al., 1978;).

Scholars interested in DCs have recently increased their attention on its micro-foundations ${ }^{2}$ (Fainshmidt, et al., 2017; Ferreira et al., 2019; Helfat and Peteraf, 2015; Helfat and Martin, 2015; Kawai, 2018; Leih and Teece, 2016; Martin, 2011; Teece, 2018; Zhang, 2007). They argue that chief executive officers (CEOs) and managers play a key role in a firm's capacity to adapt, as has already been pointed out regarding the cases of IBM (Harreld et. al., 2007), Samsung Electronics (Lee and Slater, 2007), and Smith Corona (Daneels, 2011). In all these three cases, scholars emphasize how the CEO's actions and decisions were instrumental in determining the firms' fate.).

In 2003, Adner et al. asserted that individual characteristics are a central element in an organization's general dynamic capability to change by introducing the concept of dynamic managerial capabilities $\left(\mathrm{DMCs}^{3}\right)$. Martin (2011) and Zhang (2007) argue that top managers' DMCs can be considered one of the most critical determinants of a firm's long-term competitive advantage and survival probability. DMCs highlight the importance of managers in building, integrating, and reconfiguring a firm's resource base.

${ }^{1}$ DCs have been defined as the firm's ability to integrate, build, and reconfigure internal and external competencies to address rapidly changing environments (Teece, Pisano and Shuen, 1997).

${ }^{2}$ i.e., the role of individuals in organizational DCs

${ }^{3}$ DMCs have been defined as the capabilities with which managers create, extend, and modify the ways in which firms make a living (Helfat and Martin, 2015) 
In this sense, our study is mainly built upon the foundation of the DMC approach, applying it to the context of small family firms to answer the following questions: (1) how does an ECEO's level of DMCs influence firm performance; and (2) how does family involvement moderate that relationship?

In general, our results provide several insights into how DMCs allow small family firms to survive longer and achieve superior financial performance. Also, since all the ECEOs that responded to the study questionnaire were purposely chosen for also being their firm's founders, our study is able to link to entrepreneurship, which has been argued by several authors to be of special interest to the managerial literature (Friedman et al., 2016; Teece, 2016).

Furthermore, our results support other studies that have found that dynamic capabilities have an indirect effect on performance and competitiveness, via managerial capabilities, among other variables (Ferreira et al., 2019).

Our study also shows how family firm governance structure positively moderates the positive effect of an ECEO's DMCs over the firm performance. Finally, we explore how the managerial human capital of an ECEO, one of the antecedents of DMCs, influences that ECEO's DMC levels.

\section{Theoretical Background}

\section{Dynamic Capabilities}

The recently proposed concept of DCs has its roots in other strategic theories, such as the resource-based view (RBV), transaction cost theory (TCT), behavior theory, and evolutionary theory. The DC framework extends the RBV by explaining how some firms, especially multinational ones operating in dynamic environments, can "integrate, reconfigure, renew, and recreate its resources and capabilities and, most importantly, upgrade and reconstruct its core capabilities in response to the changing environment to attain and sustain competitive advantage" (Wang and Ahmed, 2007:35). Since its emergence in the last decade of the XX century, the field of DC has advanced, but many areas remain to be developed (Ambrosini and Bowman, 2009).

From its inception, DCs have been defined in varied ways, but to some degree, all share some basic congruence. First, Teece et al. (1997) describe DCs as "the firm's ability to integrate, build, and reconfigure internal and external competences to address rapidly changing environments." Eisenhardt and Martin (2000) disaggregate DCs neither as capabilities nor abilities, but as processes to integrate, reconfigure, gain, and release resources. Teece (2000) 
disaggregated DCs in two main capabilities—sense and seizing opportunities. In 2007, Teece expanded his theory to incorporate a firm's transformation capability. In this sense, according to Teece (2007), DCs "can be disaggregated into the capacity (a) to sense and shape opportunities and threats, (b) to seize opportunities, and (c) to maintain competitiveness through enhancing, combining, protecting, and, when necessary, reconfiguring the business enterprise's intangible and tangible assets" (Teece, 2007). Furthermore, recent advances in the field of DCs has emphasize a need for a more dynamic perspective that addresses innovation in the business model (e.g., Hacklin et al., 2018; Massa et al., 2017).

\section{From Dynamic Capabilities to Dynamic Managerial Capabilities}

Although DCs have been described as an organization's meta-routine (Feldman and Pentland, 2003), this complex, intricate set of processes can be untangled to reveal the individual routines performed by specific individuals, such as executive leaders, CEOs, ECEOs, and the top management team (TMT). Building on the work done by Teece et al. (1997), Adner and Helfat (2003) introduced the concept of DMCs to stress the importance of managers' strategic role in decision making to "build, integrate, and reconfigure organizational resources and competences." This was extended by Helfat and Martin (2015) as "the capabilities with which managers create, extend, and modify the ways in which firms make a living." This definition also implies a possible modification in the current business model.

Martin (2011) mentions that DMC is "a dynamic capability;" that is, DCs encompass all levels of analysis for examining the organizational meta-routines and processes, whereas DMCs reflect the individual level of analysis of routines and processes, as highlighted by Eisenhardt and Martin (2000) and Rothaermel and Hess (2007). In a sense, managers are the facilitators of DCs. Augier and Teece (2009), and Teece (2018) argue that managers play important roles in firms, in spite of being omitted from several business and economic theories. Managers must act entrepreneurially, think strategically, and execute flawlessly to provide their organization with the capacity to sense and seize opportunities, and then transform and reconfigure according to the dictates of such opportunities and competitive forces (Augier and Teece, 2009). In this regard, the fundamental and distinctive role played by managers in the DCs framework centers on "selecting and/or developing routines, making investment choices, and in orchestrating non-tradable assets to achieve efficiencies and appropriate returns from innovation."

Martin (2011) and Zhang (2007) argue that top managers' DMCs are one of the most crucial determinants of DCs and a firm's long-term competitive advantage and survival, evidence 
to sustain such ideas can be found on the work done by Fainshmidt, et al. (2017). According to Zhang (2007), top managers' DMCs not only allow executive leaders to enhance a firm adaptability to adapt to its environment, but also let them to acquire and incorporate into the firm other valuable resources and capabilities that serve as the antecedents of valuable products and services.

\section{DMCs in Small Family Firms: Role of Entrepreneur CEOs}

Our literature review shows that numerous studies have explored the macro-foundations of DCs and how they affect organizations. However, the literature on the micro-foundations of this type of (dynamic) capabilities is more limited, with many aspects still unexplored. One of these aspects is the DMCs of major owners and general managers of small family firms.

Former studies focusing on CEOs and/or top managers and their DMC conducted their analyses in the context of large-size organizations. Furthermore, they analyze CEOs who are not necessarily the founder of the firm. Due to the importance of DCs in general and in DMCs in particular, the aforementioned arguments have motivated this study to make ECEOs' DMCs the principal subject of analysis. Furthermore, this study focuses on a very particular type of CEO, namely CEOs who are also founders of the firm they manage, referred to hereafter as an entrepreneurial CEO or ECEO.

Friedman et al. (2016) conducted a more detailed analysis of CEOs' DMCs in small firms. They found that CEOs may be more influential in small entrepreneurial firms than in larger ones, specifically in terms of influencing the firm's capacity to adapt to a changing environment. This positive influence is possible due to the fact that the CEO's transformational leadership "facilitates behavioral integration and comprehensiveness in the decision process among members of the TMT, which in turn enhances organizational capacity to adapt to environmental changes" (Friedman et al., 2016). Analyzing the structure and trends in the literature regarding family business during the period 1961-2008, Benavides-Velasco et al. (2013) identified the importance of using the RBV and DCs (Teece et al., 1997; Teece 2007) as potential avenues for future research that could be significant in advancing consolidation in the discipline.

In general, we discovered that the empirical studies in our literature review confer a positive influence from underlying managerial resources (like managerial cognition, managerial social capital, and managerial human capital) on DMCs (Bertrand and Schoar, 2003; Salvato, 2003; Tripsas and Gavetti, 2000). Also, several reviewed studies show that DMCs positively influence firm performance (Fainshmidt et al., 2016). 


\section{Research Hypothesis}

The literature review implies that the greater underlying managerial resources that a CEO possesses, the more DMCs he/she will possess, and in consequence, he/she will better enhance the firm's performance (Figure 1). Building on this view, we argue for the existence of a moderation effect of family firm governance structure on ECEO's DMC, where performance is contingent on specific firm characteristics (e.g., lifecycle stage).

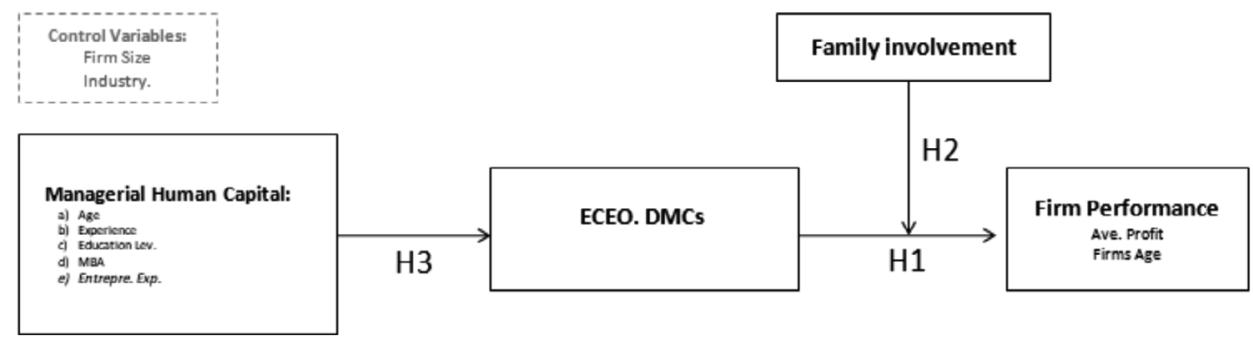

Figure. 1 Hypotheses model

Source: Own elaboration.

\section{ECEO DMCs and Firm Performance}

We discuss that if the TMT and the CEO, in particular, can have such a dramatic impact on the DCs of a firm and its performance (Augier and Teece, 2009; Fainshmidt, et al., 2017; Helfat and Peteraf, 2015; Kor and Mesko, 2013; Rodenbach and Brettel, 2012), then it is logical to think that an ECEO could have even a greater imprint on a small organization's DCs as well as on the firm's performance. Further, ECEOs could provide greater hints regarding the so-called micro-level origin of DC (Rodenbach and Brettel, 2012). These arguments are supported by a great number of theoretical and empirical studies on DCs and DMCs, many of which have been mentioned above, such as, Augier and Teece (2009), Friedman et al. (2016), Helfat and Peteraf (2015), Helfat and Martin (2015), Kor and Mesko (2013), Rodenbach and Brettel (2012), Schumpeter (1934), Teece (2016).

Prior empirical studies on DCs found a positive and significant influence on performance outcomes such as firm performance (Fainshmidt, et al., 2017; Martin, 2011; Rosenbloom, 2000; Sirmon and Hitt, 2009; Zhang and Rajagopalan, 2010); adaptive intelligence of organizations (Tripsas and Gavetti, 2000); and competitive advantage (Schilke, 2014). In this study, we are interested in measuring firm performance as an outcome variable of DMCs. 
Regarding prior empirical studies that focused on the relationship between DMCs and firm performance, Sirmon and Hitt (2009) observed that asset orchestration, a central component of DMC, generally enhances firm performance. According to them, firm performance, referring to economic performance, is measured using a market-based measure of economic performance, namely Tobin's $q$, which compares the firm's market value to the replacement costs of its assets. Furthermore, Fainshmidt, et al. (2017). found evidence that suggest that top managers' DMCs, referred as asset management capabilities, is positively associated with the in-crisis performance of the firm.

In his study, Martin (2011) explores the relationship between the DMC characteristics of the set of business-unit general managers (i.e., DMCs characteristics at group level) and firm performance. The profit measures used by Martin (2011) are return on investment or return on sales, which are similar to that used by Zhang and Rajagopalan (2010).

Firm performance can not only be measured on financial terms, but also by other means. For instance, Mann and Sager (2007) as well as Ha-Brookshire (2009) have both argued that although firm longevity alone might not be characterized as a reasonable indicator of firm success in some industries, in some contexts, like with the start-ups, longevity could generally suggest that a firm is making sufficient progress to avoid bankruptcy.

On the basis of what the previous literature indicates about DCs, we should expect a positive relationship between an ECEO DMCs and his/her firm performance, leading to the following hypothesis:

H1. A positive relationship exists between the level of an ECEO's DMCs and firm performance: profit average and firm age.

\section{Family Firms Governance Structure moderates the ECEO DMC and Firm Perfor- mance relationship}

When discussing about a family firm governance structure, it should be noted that in essence one is talking about the different ways that the family's involvement in the firm significantly influences its behavior and outcomes (e.g. performance). Family involvement in the firm could be throughout its ownership, management, and governance, aspects that researchers have long sought to understand (e.g., Daspit et al., 2018; Sharma et al., 1997). Prior studies suggest that two particular types of governance (family involvement in firm ownership and management) are among the main sources of family firm heterogeneity, and that both influences the financial performance of family firms (Daspit et al., 2018; Dekker et al., 2015; Stewart and Hitt, 2012). 
Sacristan-Navarro et al. (2011) mention that what matters is the extent to which the family is involved in management, and that ownership does not affect family firm performance and profitability. Some explanation to the later ideas is that the proportion of family members in the management team allows the implementation of family objectives within the business enabling the principal-agent alignment (Daspit et al., 2018).

In this regard, this paper focuses on one specific type of family involvement, the management one. For practical purposes, we will refer to this type of family involvement simply as the governance structure of the firm.

Family firm governance structure could have both positive and negative outcomes. Previous research has not been conclusive, and results are mixed regarding how and in what circumstances family involvement functions as an enabler resource or a barrier for growth in small firms (Rutherford et al., 2008; Zahra, 2005).

Sirmon and Hitt (2003) list some specific instances where there is a possibility that family firms have a superior competitive advantage over non-family firms, and it could be inferred that these advantages can be traced to family governance structure. Additionally, scholars have found that when a small number of family members owns and controls the business, such as the founders, their focus is predominantly on the firm's long-term economical sustainability (Schulze et al., 2003). Moreover, family members' participation in the firm's activities is generally acknowledged as essential in fostering the accumulation of socioemotional wealth, forging a shared vision and goals for the firm and generating a positive set of feelings in relation to commitment and collaboration to the business (e.g., Chirico et al., 2011; Eddleston and Kellermanns, 2007; Goel et al., 2011; Le Breton-Miller and Miller, 2013; Lubatkin et al., 2005).

Contrarily, family governance structure can have negative consequences or a "dark side" for business outcomes due to additional demands by family members, rule of primogeniture, dysfunctional conflicts, and a lack of professional knowledge (Nicholson, 2008; Schulze et al., 2001). Campopiano et al. (2014) contend that family governance structure, which is measured as the ratio of family members in key managerial positions to total number of family members working in a particular firm, can result in opportunistic behaviors and can, subsequently, prove to be detrimental to the business' sustainability.

In addition to the aforementioned studies, it should be noted that the effects of family governance structure could also be contingent upon circumstances. For instance, Jaskiewicz et al. (2013) found that nepotism could be either beneficial or harmful depending on the specific circumstances of each individual firm. Similarly, Karra et al. (2006) argue that family governance structure could be an advantage or a disadvantage depending on the stage of the 
firm. Specifically, they find that when a family firm is in its early stages, the positive effects include alignment of the interests among family members due to altruism and a reduction in the agency costs. However, as a family business becomes more mature and bigger, these benefits start decreasing.

Another study related with governance contingency is that of Madison et al. (2018). These authors suggest that family firms are heterogeneous in their application of human resources practices, and that in some instances family and nonfamily employees are treated differently, while in other both employees are treated the same. Perceptions of injustice may attenuate the firm-level benefits (e.g. enhance firm performance) associated with human resources practices of hiring more nonfamily employees.

Based on the studies above, we argue that the effect of family governance structure on performance-related outcomes in small family firms is contingent on specific firm characteristics (e.g., lifecycle stage) and the family members involved. That is, that for small family firms the family involvement should positively influence the firm performance, rather than negatively.

H2. Family governance structure will positively moderate the relationship between the level of an ECEO's DMCs and firm performance.

\section{Relationship between MHC and DMCs}

Helfat and Martin (2015) state that DMCs employ a set of underlying managerial resources: managerial cognition, managerial social capital, and managerial human capital (MHC). For these authors, the concept of MHC refers to the knowledge and learned skills that individuals develop through multiple different experiences, such as education, training, work, and extracurricular activities. MHC also includes other individual psychological attributes like general intelligence (cognitive ability), values, interests, type of leadership, and personality (Helfat and Martin, 2015).

The evidence suggests a positive relationship between the underlying managerial resources and DMC of managers and CEOs (Haunschild, 1993; Huy and Zott, 2019; McDonald and Westphal, 2003; Nadkarni and Narayanan, 2007; Prashantham and Dhanaraj, 2010). Studies further confirm the influence of MHCs on DMCs; however, the direction of such an effect is not entirely clear (Barker and Mueller, 2002; Bertrand and Schoar, 2003; Rosenbloom, 2000; Tripsas and Gavetti, 2000).

Barker and Mueller (2002), Bertrand and Schoar (2003), Datta et al. (2003), and Rothaermel and Hess (2007) noted a positive relationship between individual characteristics (age, 
experience, type of leadership, and education level, MBA possession, intellectual human capital) and certain kinds of DCs (R\&D, strategic change, diversification decision, level of investment and valuation techniques, openness to change, innovative output, and tolerance to risk aversion). More recent studies like that of Huy and Zott (2019) have gone a step further and have identified very specific underpinnings of managerial human and social capital, such as the emotion regulation, which was found to influence DMCs.

In addition, other scholars found that as CEOs age, they develop certain capabilities that could help them obtain a higher level of DCs. For instance, Robert Mitchell et al. (2011) discovered that managers with greater metacognitive experience tend to make lesser erratic strategic decisions. Similarly, Salas et al. (2010) argued that expertise-based intuition can only be developed with time and through personal experiences, and that this type of intuition can have a bigger impact on organizational performance than common general intuition.

In our literature review, among the most common variables identified with the MHC are an individual's age, experience, type of leadership, and education. However, no studies have empirically tested how MHC influences DMCs. Based on the studies above, we argue the following hypothesis:

H3. The MHC of an ECEO will be positively associated with the levels of his/her DMCs.

\section{Methods}

A quantitative survey study was conducted to examine the theory of DCs, specifically the relationship between DMCs and firm performance, which was controlled by factors such as firm age, size (sales and employees), and sector (manufacturing, services, or mixed). The unit of analysis for this study is the ECEO, and the research context comprises the small family firms in which those ECEOs work. Our general independent variable is the ECEO's level of DMCs: capabilities to sense and seize opportunities and threats, and create, extend, and/or change the ways in which firms make a living (i.e., how do managers improve their organizational DCs). The moderation variable of interest for this study is related to the family firm governance structure that was established by these ECEOs.

To test our hypotheses, we conducted a survey with a sample of 213 ECEOs from Mexican companies from diverse industries. The questionnaire went through an intensive pretesting process, with a pilot study conducted among four former ECEOs and three academic researchers (DeVellis, 2003). The questionnaire is composed of validated scales and has been published in high impact management journal in the field. Since the questionnaire was composed of 
different validated scales that were originally written in English, we rely on the use of the back-translation technique for the Spanish version of the questionnaire.

The final version was administered either online or face-to-face; in both cases, the questionnaire was self-administered by respondents. We used a three-wave mailing approach via e-mail, in accordance with Dillman (1978), to obtain more responses. From the total mailing list of 750 emails, we received 110 responses from Mexican ECEOs, giving a response rate of $14.6 \%$, which is higher than the $9 \%$ proposed by Klassen and Jacobs (2001). We also collected 103 responses via face-to-face self-administration of the questionnaire. Data collection took place from July 2016 to February 2017.

We compared respondents with non-respondents by running the Mann-Whitney U tests concerning different important variables like firm sales, number of employees, and firm age. No significant differences were discovered between the respondents and non-respondents, either in the e-mailed or in-situ surveys. Therefore, we find no evidence that suggests a significant non-response bias in our data.

Also, in order to verify the suitability of the selected key informants, we included some questionnaire items that asked whether the respondent founded the firm and/or ran the business as ECEO. We also asked if the respondent had founded more than one business. In case of the respondents who had founded more than one, we explicitly asked them to focus on only one of their businesses.

Finally, all the aforementioned procedures were used with the aim of increasing the quality of responses (Cycyota and Harrison, 2006). For instance, all respondents were assured full anonymity of the information given.

\section{Sample}

\section{Sample Design}

The empirical analysis is mainly based on survey data collected from ECEOs of small enterprises located in totality within Mexico. SMEs are firms that have no more than 250 employees or annual sales of no more than $€ 50$ million. According to the standards given by the Organization for Economic Co-operation and Development (OECD), Economic Commission for Latin America and the Caribbean (CEPAL), and Instituto Nacional de Estadística, Geografía e Informática (INEGI, 2019) a firm is considered small if it has between 10 and 49 employees, and medium if it has between 50 and 250 employees. 
According to Wilden et al. (2013), small and medium firms tend to have more emergent strategies and a less formalized division of responsibilities. Furthermore, Friedman et al. (2016) argues that small and medium-sized firms are great candidates to study DCs and DMCs.

\section{Sample Selection}

The sampling technique used to select subjects was convenience sampling because access to our key informants was hard to obtain, given their limited time availability unless the researcher was recommended by someone close to the interviewee. Convenience sampling is a procedure in which "the researcher selects participants because they are willing and available to be studied" (Creswell, 2005:149).

In addition to convenience sampling, we ensured that all our observations came from an ECEO, which, as we mentioned earlier, is defined as an entrepreneur who is the founder as well as CEO of the company under study.

Table 5.1 provides descriptive information about the whole sample. In regards to firm size, our results are similar to those reported by INEGI (2019) in Mexico: 95.9\% are micro, $3.3 \%$ small, $0.7 \%$ medium, and $0.2 \%$ large. About the ECEOs' profile, they are an average of 37.25 years old, $50.7 \%$ are male, and $49.3 \%$ are female. Although the great equality in gender participation could be unexpected, these results are supported by some official government reports, i.e., INJUVE (2014). The ECEOs in our sample have an average of 15.67 years of formal education. 
Table 1

Sample's descriptive statistics.

\begin{tabular}{ll}
\hline Variable & Value \\
\hline Firm Profile & \\
Micro Firms (0-10 employees), & $87.3 \%$ \\
Small Firms (11-50 employees), & $11.74 \%$ \\
Medium Firms (51-250 employees), & $0.94 \%$ \\
Average Number of Years Operating & 4.55 years \\
Sector & \\
Service & $69.01 \%$ \\
Manufacturing & $30.99 \%$ \\
ECEOs Profile & \\
Average Years Old & 37.25 years \\
Output Work experience (R\&D, sales, marketing) & $36.61 \%$ \\
Throughput Work experience (legal, finance, administra- & $63.39 \%$ \\
tion, production) & \\
Novice Type of Entrepreneur & $59.15 \%$ \\
Serial/Portfolio Type of Entrepreneur & $40.85 \%$ \\
Average Years of Formal Education & 15.67 years \\
With Undergraduate Degree & $28 \%$ \\
With Graduate Degree & $15 \%$ \\
With MBA Degree & $10 \%$ \\
Average Women & 4.55 \\
Average Men & $50.7 \%$ \\
Dependent Variable & \\
Average Number of Years Operating & \\
Firms Maximum Revenue & \\
Independent Variable & \\
DMCs Wilden (Average 7 points Likert) & \\
Moderation Variable & \\
Average Number of Family Member Working in the Firm & \\
\hline & \\
\hline
\end{tabular}

Source: Own elaboration. 


\section{Scale Development and Measures}

\section{Independient Variable: DMCs}

This study measures one complex construct, namely DMCs (independent variable). The scale was adapted from Wilden et al. (2013), who developed and validated a scale to measure dynamic capabilities from an organizational perspective instead of an individual one. We decided to adapt this scale after meticulously contrasting the theoretical differences between DCs and DMCs. One of the great advantages of Wilden et al. (2013)'s scale is that it can be broadly applied to many different types of organizations. Another advantage is that instead of measuring a specific type of dynamic capability, as is the case with most of the other scales in the literature, it measures the three sub-dimensions of DCs proposed by Teece (2007): sensing, seizing, and reconfiguring. The instrument was developed as a reflective measurement model.

Respondents were asked to assess how much they contributed into the processes that emerge from the three original dimensions of DCs on a seven-point interval Likert scale, where $1=$ rarely or extremely infrequent and $7=$ extremely frequent. Table 2 presents the constructs for measuring DCs exhibited convergent and discriminant validity. All Cronbach's alpha values were above the suggested value of 0.70 (Subramaniam and Youndt, 2005), and all loadings and weights were significant at the 0.001 level (2-tailed). Therefore, the instrument for measuring DMCs is valid and internally consistent. Discriminant validity was inspected using the Fornell and Larcker (1982) criterion, which basically states that in order for discriminant validity to exist, the AVE should be larger than the square root of its largest correlation with any construct, which all the constructs of DCs fulfilled.

Table 2

Constructs Validity and Reliability Scores

\begin{tabular}{lllll}
\hline & AVE & CR & $\alpha$ (Cronbach's alpha) & AVE $>$ Corr $^{2}$ \\
\hline DCs & 0.40 & 0.89 & 0.86 & $0.40>0.03$ \\
Sensing & 0.54 & 0.82 & 0.71 & $0.54>0.52$ \\
Seizing & 0.63 & 0.87 & 0.81 & $0.63>0.52$ \\
Transforming & 0.67 & 0.89 & 0.84 & $0.67>0.16$ \\
\hline
\end{tabular}

Source: Own elaboration. 


\section{Dependent Variable: Firm Performance}

Agle et al. (2006) pointed out that the operationalization of a variable like organizational performance has always been a challenge to scholars, and the literature on strategy, finance, and accounting has long suggested that both market and accounting-based measures suffer from a number of issues, like measurement and controllability, and that these different measures might even represent different constructs of organizational performance.

In these latter cases, the alternative option to measure any type of organizational performance is that which is perceived by the key informants. To this matter, Delaney and Huselid (1996: 954) explain that researchers have found that measures of perceived organizational performance positively correlate with "objectives measures of firm performance".

In consequence, we decided to use two practical measures of financial performance. The first measurement is firm longevity. Respondents were asked for how long the firm has been in operation. The second is financial performance; basically, we asked for the average net income or profit for the total time the firm has been in operation.

\subsubsection{Moderation Variable: Family firm governance structure}

Family firm governance structure has been measured by scholars in different ways. For instance, Campopiano et al. (2014) measured the ratio between the number of family members serving as managers and number of family members working in the firm. Kotlar et al. (2014) measured only the number of family members working for the firm. Zahra et al. (2007) measured family involvement using two fairly simple metrics: (1) the number of generations involved in management, and. (2) the percentage of top managers who are family members.

This study measured family firm governance structure in a similar manner that Kotlar et al. (2014), i.e., the total number of family members, including the extended family members, working in the firm, regardless of whether part-time or full-time, or formally or informally.

\section{Control Variables}

To test our hypotheses, several control variables that could influence the DMCs of ECEOs were specifically controlled for. Following Danneels (2008), we controlled for firm size and industry sector (goods or services). Firm size was measured by the number of employees (full-time-equivalent employees). Industry sector was differentiated with a dummy variable, whereby firms in the manufacturing sector were coded as 0 , firms in the service sector were 
coded as 1, and mixed firms were coded as 2 (Rodebach and Brettel, 2012; Wilden et al., 2013). Therefore, two effect-coded variables were included as controls for industry.

\section{Results and Discussion}

Prior our statistical model testing and in order to develop our structural equation modeling, we first ensured that the data being evaluated complied with structural equation modeling (SEM) assumptions. We followed the main steps to develop a SEM model as recommended in literature (Weston and Gore Jr, 2006). Specifically, the assumptions analyzed for this study are as follows: sample size, multicollinearity, singularity, normality, and continuous variables.

Sample Size. Sample size has a direct effect on the predictive power of any statistical model, including SEM. The final sample size for this research is 213 observations, which could be considered sufficient according to the rule of thumb suggested in the literature (Tabachnick and Fidell, 2007; Hair et al. 2006; Luque, 2000).

Multicollinearity. Estimation with SEM can only be done properly if none of the independent variables in the model are perfectly correlated (Guillén, 1992). Our model contains no high correlation cases, a value higher than 0.80 is typically taken as indicating a multicollinearity problem (see Table 3). Additionally, we checked the Variance Inflated Factor (VIF) in all of our regressions models, and the highest value was below the threshold value of 10 given as a rule of thumb (Hair et al., 2006).

Normality. All analyzed variables in a regression model are required to be normally distributed to guarantee that the critical values do in fact determine the significance of each coefficient (Cea, 2002: 521). We first checked for individual normality in each variable in the model, which we then corroborated by checking for multivariate normality. Skewness values should be within the range \pm 1 for normal distribution, and for kurtosis, values should be within range \pm 3 for normal distribution (Cea, 2002: 521; Lowry and Gasking, 2014; Weston, and Gore Jr, 2006; 735). In the present study all variables fit well /are well fit with these criteria. 
Table 3

Correlations, Means, Standards Deviations, and Ranges

\begin{tabular}{|c|c|c|c|c|c|c|c|c|c|c|c|}
\hline & 1 & 2 & 3 & 4 & 5 & 6 & 7 & 8 & 9 & 10 & 11 \\
\hline 1. DMCs & 1 & & & & & & & & & & \\
\hline 2. Fam. Involvement & $0.246^{* *}$ & 1 & & & & & & & & & \\
\hline 3. ECEO age & $0.135 *$ & 0.052 & 1 & & & & & & & & \\
\hline 4. MBA Edu & $0.283^{* *}$ & $0.248^{* *}$ & 0.066 & 1 & & & & & & & \\
\hline 5. LevEduc (cont) & $0.149^{*}$ & 0.079 & $0.175 *$ & $0.325^{* *}$ & 1 & & & & & & \\
\hline 6. Entre. Exper & $0.172^{*}$ & $0.302^{* *}$ & $0.160^{*}$ & $0.283^{* *}$ & $0.185^{* *}$ & 1 & & & & & \\
\hline 7. $\operatorname{Exp}($ cont) & $0.143^{*}$ & 0.099 & 0.052 & 0.094 & 0.069 & -0.037 & 1 & & & & \\
\hline 8. Profit Average & $0.479 * *$ & $0.162^{*}$ & 0.040 & $0.150^{*}$ & 0.075 & 0.082 & $0.141^{*}$ & 1 & & & \\
\hline 9. Firms Years & $0.543^{* *}$ & 0.071 & $0.411^{* *}$ & 0.130 & $0.197 * *$ & $0.231^{* *}$ & $0.156^{*}$ & $0.318^{* *}$ & 1 & & \\
\hline 10. Firm Size & $0.334^{* *}$ & $0.260 * *$ & -0.050 & $0.169^{*}$ & 0.122 & 0.105 & 0.116 & $0.714^{* *}$ & $0.200^{* * *}$ & 1 & \\
\hline 11. Industry & 0.064 & -0.063 & 0.015 & 0.027 & 0.011 & -0.001 & -0.123 & 0.060 & 0.075 & 0.023 & 1 \\
\hline Mean & 3.817 & 1.554 & 37.254 & 0.103 & 15.678 & 0.408 & 0.366 & 1290493 & 4.553 & 6.573 & 1.690 \\
\hline Std. Deviation & 1.676 & 1.357 & 12.469 & 0.305 & 2.121 & 0.493 & 0.483 & 1278547 & 4.069 & 8.274 & 0.464 \\
\hline Range ---- High & 16 & 8 & 72 & 1 & 19 & 1 & 1 & 5000000 & 24.800 & 54 & 2 \\
\hline Low & 1.300 & 0 & 18 & 0 & 10 & 0 & 0 & 25000 & 0.100 & 0 & 1 \\
\hline
\end{tabular}

Source: Own elaboration.

\section{Theory testing}

Figure 2 presents the results of testing all our variables from the full theoretical model. The model estimation was made with the AMOS software, considering the values of the path coefficients or standardized regression weights () and the variance explained (R2). DMC is a first-order latent variable which is measured by three observable variables each of them represent the dynamic managerial capabilities: sense (Wsens), seize (WSez) and transform (WTrans).

Firm performance is an observable variable measured by profit average (profit Ave) and firm age (Firm Age).

MHC is a first-order latent variable which is measured by five observable variables such as: ECEO age (EntreAge), carrer experience (CarrerExp), education level (EduLev), postgraduate studies (MBA), entrepreneurial experience (Entrepre.Exp).

Firm size (Firm Size) and industry (Industry) are introducing as control variables.

The measures of model fit in Figure 2 also provide additional support for the fit of our theoretical model to the data. In many cases, the measures suggest an acceptable fit between the model and obtained data. Therefore, this supports the likelihood that our theoretical model is represents the actual experiences of the business owners in our sample. The most typical reported model fit indexes and the most common cutoff values are chi-square (CMIN/DF) 
less than 3 (for the present study is 2.47), CFI greater than .90 (.894), NFI greater than .80 (.836), and RMSEA less than .08 (.083) (Hair et al. 1999; Weston and Gore Jr, 2006).

Hypothesis 1 examined the relationship between the level of an ECEO's DMCs and firm performance. The model in Figure 1 shows that ECEO's DMCs are positively and significantly influential only when longevity is used to measure performance not for financial terms (annual profit average). The probability for this test is less than $0.001(p<0.001)$, thus partially supporting hypothesis 1 . A standardized regression weight of 0.62 indicates that ECEO's DMCs influence the level of firm performance. Statistically, this means that a firm's performance improves by approximately 0.62 standard deviation units when the CEO's DMCs increases by one standard deviation.

Our findings support theory that exposes an ECEO's level of DMCs positively influences his/her firm's performance. This finding is consistent with the literature (Martin, 2011; Rosenbloom, 2000; Sirmon and Hitt, 2009; Zhang and Rajagopalan, 2010), specifically, when performance is measured in terms of longevity, such as the number of years that the firm has been operating, instead of financial terms (annual profit average). This could imply that in small family firms, ECEO DMCs are more relevant to firm survival than financial indicators. As Friedman et al. (2016) study findings show that CEOs may be more influential in small entrepreneurial firms' capacity to adapt to a changing environment. Sensing the environment, seizing and combining external knowledge, and transforming organizational resources and capabilities over time may be more crucial to smaller family firms' ability to develop new opportunities for growth and thus to stay in the market and survive in the first years.

Hypothesis 2 proposed that the family firm governance structure will positively moderate the relationship between ECEO DMC levels and firm performance. The findings reported in Figure 2 reveal that family firm governance structure strengthens the positive relationship between the level of an ECEO's DMCs and firm performance, for this hypothesis 2 is confirmed. A standardized regression weight of 0.69 indicates that family involvement has a very considerable influence over this relationship.

In relation to our findings that family firm governance structure strengthens the relationship between the level of an ECEO's DMCs and firm performance, we have two important issues to discuss. First, the positive and significant relationship observed in the results lead us to argue that when doing research with small firms, scholars should consider the implications of how small family-firm governance structure is measured. It is often common in family firm research to only account for family members who formally work for the firm, omitting family members that participate informally or on a part-time basis. Our observed evidence suggests that in small family firms, especially in their early stages, family members generally carry 
out many tasks without being formally remunerated, but they are highly involved in making decision process. This finding supports Schulze et al., (2003) study in which researchers found that when a small number of family members owns and controls the business, such as the founders, their focus is predominantly on the firm's long-term economical sustainability.

Second, this results also contradict those of scholars who argue that family firm governance structure negatively affects performance (Campopiano et al., 2014; Kellermanns et al., 2012; Nicholson, 2008; Schulze et al., 2001, 2003). However, as acknowledged earlier, some researchers have argued that in some instances, the effects of family firm governance structure might be contingent on individual and organizational characteristics (e.g., type of nepotism, or size and stage of the firm) (Jaskiewicz, et al., 2013; Karra. et al., 2006). Therefore, one explanation is that in early stages of a family firm, i.e., when it is small with only a few family members as employees, the positive influence of family firm governance structure will be greater than any negative influence, but this could change and differ from the relationship found in larger and more mature firms.

Hypothesis 3 tested the antecedent role of an ECEO's MHC on his/her level of DMCs, stating that this relationship will be positive. The model in Figure 2 demonstrates that MHC is positively and significantly related to ECEO's DMCs with a probability less than 0.001 ( $p$ $<0.001)$. Thus, hypothesis 3 is upheld. A standardized regression weight of 0.51 indicates that a ECEO's MHC influences their DMC levels. Statistically, this means that a ECEO's DMCs is improved by approximately 0.51 standard deviation units for every one standard deviation increase in the ECEO's MHC.

This finding indicates that ECEOs of a certain age and having certain levels and types of formal education (graduate studies, preferably an MBA), and with a high level of entrepreneurial experience tend to have higher levels of DMCs, This confirms that skills from different organizational areas could be related to DCs, like R\&D, strategic change, investment and valuation techniques, risk aversion, strategic decisions, and expertize-based intuition (Barker and Mueller, 2002; Bertrand and Schoar, 2003; Khatri and Ng, 2000; McDonald and Westphal, 2003; Nadkarni and Narayanan, 2007; Prashantham and Dhanaraj, 2010; Robert Mitchell, et al., 2011; Salas Rosen and Diaz Granados, 2010).

Achieving a higher level of education and/or possessing an MBA should be related with having a greater ability to sense, and seize opportunities and threats, and to transform the assets of a firm in order to sustain its competitive advantage. Education can enhance an individual's cognitive abilities, which in turn will prepare him to couple better with business and environmental changes Bertrand \& Schoar, 2003). In this sense, in our literature review related to educational level, we found that higher education level is associated with i) a grea- 
ter tolerance for ambiguity, which is required on dynamic environments and changes in the firm's strategy; ii) an increased ability to process multiple alternatives, which is extremely necessary for a CEOs/ECEOs in order to sense and evaluate multiple opportunities and; iii) a source of innovation which is needed in order to create, extend, and modify the ways in which firms make a living.

Moreover, future research is needed in order to understand whether or not the possession of an MBA education by an ECEO is essential not only in influencing a greater level of DMCs, as our results shows, but also in specifically showing higher levels of one specific component of the DMCs, the seizing capability.

This list leads one to argue that entrepreneurial experience could be included as a new variable to evaluate the construct of MHC. The results of the present study indicate a clear need for further research, supported by the theoretical definition of DMCs and MHCs (Helfat and Martin, 2015) in conjunction with the current literature on individual experience (Barker and Mueller, 2002; Dearborn and Simon, 1958; Finkelstein and Hambrick, 1996).

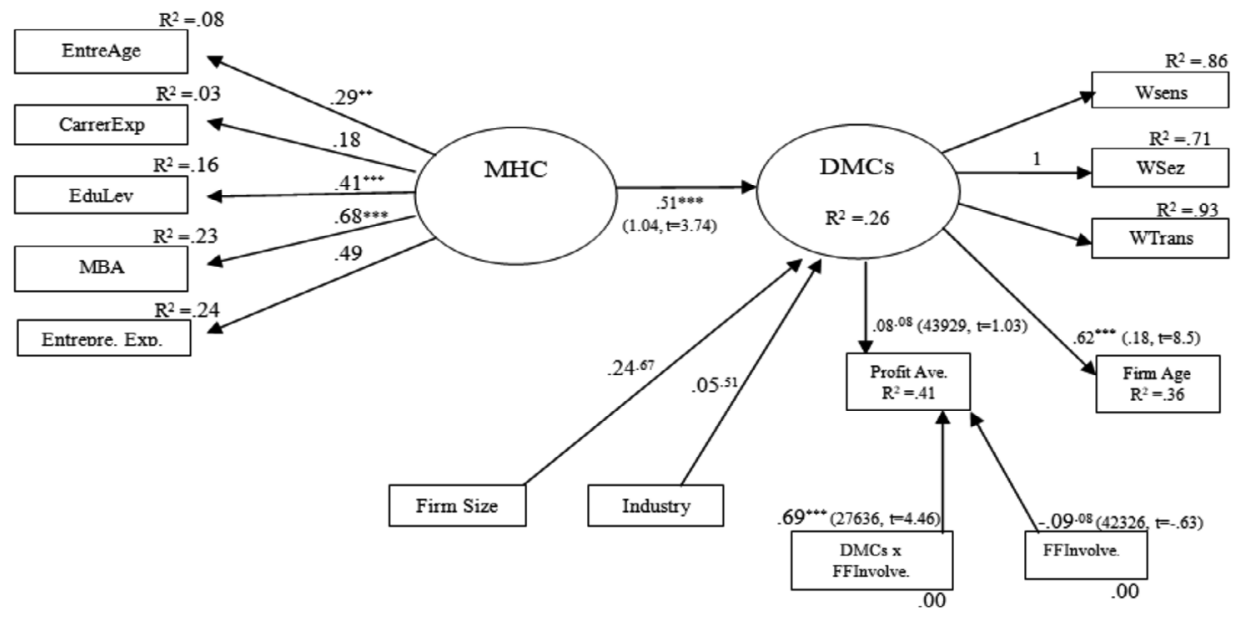

Figure. 2 Complete SEM Model Testing

Source: Own elaboration.

\section{Conclusions}

To survive in a business environment where change is permanent, small business firms require CEOs able to sense, seize, and transform their organization, abilities often called DMCs. In that sense, this study emphasizes that, in addition to organizational dynamic capabilities, small 
business firms need to develop and/or strengthen their CEOs DMC in order to respond, adapt, and survive in the market. This study reveals certain characteristics of entrepreneur CEOs (ECEO), e.g., those related to their MHC like age, formal education, and entrepreneurship experience, have a significant impact on their ability to lead their organizations in uncertain and unpredictable business scenarios.

The construct of dynamic capabilities has been extensively explored by strategic management researchers for the last two decades. However, Chirico and Norvquist (2010) observed that only a few studies have focused on dynamic capabilities in family firms, and we might add that none have studied DMCs in these kinds of organizations. Our study therefore adds novel insights to the literature of dynamic capabilities and entrepreneurship by extending this concept to family firms and to understand how the entrepreneurial experience of an ECEO influences his DMCs.

A significant aspect for these kinds of firms is family firm governance structure, either as full-time, part-time, or only occasional participation, family members offer additional support to the ECEO's adaptability efforts. Hence, our findings provide practical implications for practitioners by understanding how the managerial human capital of an ECEO (age, career experience, education, entrepreneurial experience) might influence his DMCs and the strategic change of a firm and even its performance. For instance, individuals aged around 50 and with an MBA have greater chances to positively contribute to the development or strengthening of organizational dynamic capabilities. we have found some evidence that indicates, although not conclusively, that this is the optimal range for an ECEO to exhibit a greater level of DMCs. On the other hand, ECEOs/CEOs that are very young or very old will tend to exhibit lower levels of DMCs, therefore should be considerate for firms that operates in more stable environments.

Besides age, there are other aspects of the human capital of an ECEO/CEO that should be considerate when the sensing, or seizing opportunities and threats, or for transforming the resource in a firm is essential for its success. These aspects are an individual's education and entrepreneurial experience. Regarding to education, there is evidence that indicates that the greater the number of years of formal education that an ECEO have, the greater the chances he will exhibit greater levels of DMCs, and in consequence a greater chance for a better performance of the firm.

For further research, the present study findings raise several questions whose answers would provide greater understanding of family businesses and DMCs. Firstly, most previous research has focused on family members formally involved in the firm, as indicated by Tabor et al. (2018), who have made a call to direct the research agenda toward the study of other 
types of family members that can influence a family firm. In this sense, the different roles and influences that family members who are not formally working full-time in family firms could have over the firm are not fully understood.

Second, we argue that family members fitting this description could serve as gatekeepers for the family firm (i.e., bring new information and ideas to the family firm from outside) because their part-time or sporadic involvement in the family enterprise could give them the opportunity to be involved with other organizations, even though more studies are needed to expand this finding.

Third, our literature review of DMCs indicates that scholars have focused their efforts on testing only one of the underlying managerial resource of DMCs, namely that of MHC. However, much remains unknown about the other types of resources, such as managerial social capital, managerial cognition, and entrepreneurial experience.

Finally, some limitations of the present study should be taken into account. First, the cross-sectional nature of the study means that the conclusions are tentative; reverse causality might be present. Second, firm performance could be measured as a growth rate or profit average, even though in the present study was measured as firm longevity confirming how Dynamic Managerial Capabilities (DMC) impact on firm sustainability. Third, the sample study of this study is entirely from Mexico, which can limit the transferability of our findings.

\section{References}

Adner, R., \& Helfat, C. E. (2003). Corporate effects and dynamic managerial capabilities. Strategic Management Journal, 24(10), 1011. https://doi.org/10.1002/smj.331

Agle, B. R., Nagarajan, N. J., Sonnenfeld, J. A., \& Srinivasan, D. (2006). Does CEO charisma matter? An empirical analysis of the relationships among organizational performance, environmental uncertainty, and top management team perceptions of CEO charisma. Academy of Management Journal, 49(1), 161. https://doi. org/10.5465/amj.2006.20785800

Ambrosini, V., \& Bowman, C. (2009). What are dynamic capabilities and are they a useful construct in strategic management? International Journal of Management Reviews, 11(1), 29. https://doi.org/10.1111/j.1468-2370.2008. 00251.x

Augier, M. \& Teece, D. J. (2009) 'Dynamic capabilities and the role of managers in business strategy and economic performance,' Organization Science, 20 (2), 410. https://doi.org/10.1287/orsc.1090.0424

Barker III, V. L., \& Mueller, G. C. (2002). CEO characteristics and firm R\&D spending. Management Science, 48(6), 782-801. https://doi.org/10.1287/ mnsc.48.6.782.187

Benavides-Velasco, C. A., Quintana-García, C., \& Guzmán-Parra, V. F. (2013). Trends in family business research. Small business economics, 40(1), 41-57. https://doi.org/10.1007/s11187-011-9362-3

Bertrand \& Schoar (2003) Managing with Style: The Effect of Managers on Firm Policies. Quarterly Journal of Economics, 118(4), 1169-1208. https://doi.org/ 10.1162/003355303322552775

Campopiano, G., De Massis, A., \& Chirico, F. (2014). Firm philanthropy in small-and medium-sized family firms: The effects of family involvement in ownership and management. Family Business Review, 27(3), 244-258. https:// doi.org/10.1177/0894486514538450 


\section{S. S. Guajardo Treviño, et al./ Contaduría y Administración 65(3), 2020, 1-28}

http://dx.doi.org/10.22201/fca.24488410e.2020.2132

Cea, M.A. (2001). Metodología cuantitativa. Estrategias y técnicas de investigación social. Madrid: Editorial Síntesis. https:// doi:10.2307/40183928

Chirico, F., \& Nordqvist, M. (2010). Dynamic capabilities and trans-generational value creation in family firms: The role of organizational culture. International Small Business Journal, 28(5), 487-504. https://doi. org/10.1177/0266242610370402

Chirico, F., Sirmon, D. G., Sciascia, S., \& Mazzola, P. (2011). Resource orchestration in family firms: Investigating how entrepreneurial orientation, generational involvement, and participative strategy affect performance. Strategic Entrepreneurship Journal, 5, 307-326. https://doi.org/10.1002/sej.121

Creswell, J. W. (2005). Educational research: Planning, conducting, and evaluating quantitative and qualitative research (2nd ed.) Berkeley, CA: Carlisle Communications. Retrieved on May 05, 2019, from: https://www.pearson.com/ us/higher-education/product/Creswell-Educational-Research-Planning-Conducting-and-Evaluating-Quantitative-and-Qualitative-Research-4th-Edition/9780131367395.html

Cycyota, C. S., \& Harrison, D. A. (2006). What (not) to expect when surveying executives, a meta-analysis of top manager response rates and techniques over time. Organizational Research Methods, 9(2), 133-160. https:// doi.org/10.1177/ 1094428105280770

Danneels, E. (2008). Organizational antecedents of second order competences. Strategic Management Journal, 29(5), 519-543. https://doi.org/10.1002/smj.684

Danneels, E. (2011). Trying to become a different type of company: Dynamic capability at Smith Corona. Strategic Management Journal, 32(1), 1-31._https://doi.org/10.1002/smj.863

Daspit, J. J., Chrisman, J. J., Sharma, P., Pearson, A. W., \& Mahto, R. V. (2018). Governance as a source of family firm heterogeneity. https://doi.org/10.1016/j.jbusres.2017.12.041

Datta, D. K., Rajagopalan, N., \& Zhang, Y. (2003). New CEO openness to change and strategic persistence: The moderating role of industry characteristics. British Journal of Management, 14(2), 101-114. https://doi. org/10.1111/1467-8551.00268

Dearborn, D. C., \& Simon, H. A. (1958). Selective perception: A note on the departmental identifications of executives. Sociometry, 140-144. https://doi.org/ 10.2307/2785898

Delaney, J. T., \& Huselid, M. A. (1996). The impact of human resource management practices on perceptions of organizational performance. Academy of Management journal, 39(4), 949-969. https://doi.org/ 10.5465/256718

Dekker, J., Lybaert, N., Steijvers, T., \& Depaire, B. (2015). The effect of family business professionalization as a multidimensional construct on firm performance. Journal of Small Business Management, 53(2), 516-538. https://doi.org/10.1111/jsbm.12082

DeVellis, R. F. (2012). Scale development: Theory and applications (Vol. 26). Sage publications. Retrieved on May 31, 2019, from: https://us.sagepub.com/en-us/nam/scale-development/book246123

Dillman, D. A. (1978). Mail and telephone surveys (Vol. 3). Wiley Interscience. https://doi: 10.2307/3150885

Eddleston, K. A., \& Kellermanns, F. W. (2007). Destructive and productive family relationships: A stewardship theory perspective. Journal of Business Venturing, 22, 545-565. https://doi.org/10.1016/j.jbusvent.2006.06.004

Eisenhardt, M. E., \& Martin, J. A. (2000): Dynamic Capabilities: What are they? Strategic Management Journal, 21, 105-1121. https://doi.org/10.1002/1097-0266(200010/11)21:10/11<1105::AID-SMJ133>3.0.CO;2-E

European Commission SMEs (2003). What is SME? Retrieved on March 12, 2018, from: http://ec.europa.eu/enterprise/policies/sme/facts-figures-analysis/sme-definition/index_en.html

Fainshmidt, S., Pezeshkan, A., Lance Frazier, M., Nair, A., \& Markowski, E. (2016). Dynamic Capabilities and Organizational Performance: A Meta Analytic Evaluation and Extension. Journal of Management Studies, 53(8), 1348-1380. https://doi.org/10.1111/joms.12213

Fainshmidt, S., Nair, A., \& Mallon, M. R. (2017). MNE performance during a crisis: An evolutionary perspective on the role of dynamic managerial capabilities and industry context. International Business Review, 26(6), 1088-1099. https://doi.org/10.1016/j.ibusrev.2017.04.002 
Feldman, M. S., \& Pentland, B. T. (2003). Reconceptualizing organizational routines as a source of flexibility and change. Administrative science quarterly, 48(1), 94-118. https://doi.org/10.2307/3556620

Ferreira, J. A. B., Coelho, A., \& Weersma, L. A. (2019). The mediating effect of strategic orientation, innovation capabilities and managerial capabilities among exploration and exploitation, competitive advantage and firm's performance. Contaduría y Administración, 64(1), 49-50. http://dx.doi.org/10.22201/fca.24488410e.2019.1918

Finkelstein, S., \& Hambrick, D. C. (1996). Strategic leadership: Top executives and their effects on organizations. South-Western Pub. https://doi.org/10.1177/031289629702200205

Fornell, C., \& Larcker, D.F. (1981). Evaluating structural equation models with unobservable variables and measurement error. Journal of Marketing Research 18, 39-50. https://doi.org/10.1177/002224378101800104

Friedman, Y., Carmeli, A., \& Tishler, A. (2016). How CEOs and TMTs Build Adaptive Capacity in Small Entrepreneurial Firms. Journal of Management Studies, 53(6), 996-1018. https://doi.org/10.1111/joms.12184

Goel, S., He, X., \& Karri, R. (2011). Family involvement in a hierarchical culture: Effect of dispersion of family ownership control and family member tenure on firm performance in Chinese family owned firms. Journal of Family Business Strategy, 2(4), 199-206. https://doi.org/10.1016/j.jfbs.2011.10.003

Guillén, M. F. (1992) Análisis de Regresión Múltiple. Cuadernos Metodológicos. Madrid: Centro de Investigaciones Sociológicas. Retrieved on March 12, 2018, from: https://libreria.cis.es/libros/analisis-de-regresion-multiple/9788474766486/

Ha-Brookshire, J. E. (2009). Does the firm size matter on firm entrepreneurship and performance? US apparel import intermediary case. Journal of Small Business and Enterprise Development, 16(1), 132-146. DOI $10.1108 / 14626000910932926$

Hacklin, F. , Bjorkdahl, J.\& Wallin, M.W. (2018). Strategies for business model innovation: How firms reel in migrating value, Long Range Planning, 51(1),82-110. https://doi.org/10.1016/j.lrp.2017.06.009

Hair, J. F., Anderson, R. E., Tatham, R. L., \& Black, W. C. (1999). Análisis multivariante (Vol. 491). Madrid: Prentice Hall.

Hair, J. F., Black, W. C., Babin, B. J., Anderson, R. E., \& Tatham, R. L. (2006). Multivariate data analysis (Vol. 6). Upper Saddle River, NJ: Pearson Prentice Hall.

Harreld, J. B., O`Reilly, C. A., \& Tushman, M. L. (2007). Dynamic capabilities at IBM: Driving strategy into action. California Management Review, 49(4), 21-43. https://doi.org/10.2307/41166404

Haunschild, P. R. (1993). Interorganizational imitation: The impact of interlocks on corporate acquisition activity. Administrative science quarterly, 564-592. https://doi.org/10.2307/2393337

Helfat, C. E., \& Martin, J. A. (2015). Dynamic managerial capabilities: Review and assessment of managerial impact on strategic change. Journal of Management, 41(5), 1281-1312. https://doi.org/10.1177/0149206314561301

Helfat, C. E., \& Peteraf, M. A. (2015). Managerial cognitive capabilities and the microfoundations of dynamic capabilities. Strategic Management Journal, 36(6), 831-850. https://doi.org/10.1002/smj.2247

Huy, Q., \& Zott, C. (2019). Exploring the affective underpinnings of dynamic managerial capabilities: How managers' emotion regulation behaviors mobilize resources for their firms. Strategic Management Journal, 40(1), 28-54. https://doi.org/10.1002/smj.2971

INEGI (2019). Censo Económico 2014 / Instituto Nacional de Estadística y Geografía.-- México: INEGI. Retrieved on May 31, 2019, from: https://www.inegi.org.mx/contenidos/programas/ce/2014/doc/frrdf_ce2014.pdf.

INJUVE (2014). Retrieved on May 31, 2019, from: ttp://www.imjuventud.gob.mx/pagina.php?pag_id=956.

Jaskiewicz, P., Uhlenbruck, K., Balkin, D. B., \& Reay, T. (2013). Is nepotism good or bad? Types of nepotism and implications for knowledge management. Family Business Review, 26(2), 121-139. https://doi.org/10.1177/0894486512 470841

Karra, N., Tracey, P., \& Phillips, N. (2006). Altruism and agency in the family firm: Exploring the role of family, kinship, and ethnicity. Entrepreneurship Theory and Practice, 30(6), 861-877. https://doi. org/10.1111/j.1540-6520. 2006.00157x 


\section{S. S. Guajardo Treviño, et al. / Contaduría y Administración 65(3), 2020, 1-28}

http://dx.doi.org/10.22201/fca.24488410e.2020.2132

Kawai, T. (2018). Proposing a Theory of Dynamic Managerial Capabilities $\square$ For Coping with the Era of IoTu. Journal of Strategic Management Studies, 10(1), 35-52. https://doi.org/10.24760/ iasme.10.1_35

Kellermanns, F. W., Eddleston, K. A., \& Zellweger, T. M. (2012). Extending the socioemotional wealth perspective: A look at the dark side. Entrepreneurship Theory and Practice, 36(6), 1175-1182. https:// doi.org/10.1111/j.1540-6520. 2012.00544x

Khatri, N., \& Ng, H. A. (2000). The role of intuition in strategic decision making. Human relations, 53(1), 57-86. https://doi.org/10.1177/0018726700531004

Klassen, R. D., \& Jacobs, J. (2001). Experimental comparison of web, electronic and mail survey technologies in operations management. Journal of Operations Management, 19(6), 713-728. https://doi.org/10.1016/S02726963(01)00071-7

Kor, Y. Y., \& Mesko, A. (2013). Dynamic managerial capabilities: Configuration and orchestration of top executives' capabilities and the firm's dominant logic. Strategic Management Journal, 34(2), 233-244. https://doi.org/10.1002/smj. 2000

Kotlar, J., De Massis, A., Fang, H., \& Frattini, F. (2014). Strategic reference points in family firms. Small Business Economics, 43(3), 597-619. https://doi.org/10. 1007/s11187-014-9556-6

Le Breton-Miller, I., \& Miller, D. (2013). Socioemotional wealth across the family firm life cycle: A commentary on "Family business survival and the role of boards." Entrepreneurship Theory and Practice, 37, 1391-1397. https://doi. org/10.1111/etap.12072

Lee, J., \& Slater, J. (2007). Dynamic capabilities, entrepreneurial rent-seeking and the investment development path: The case of Samsung. Journal of International Management, 13(3), 241-257. https://doi.org/10.1016/j. intman. 2007.05.003

Leih, S., \& Teece, D. (2016). Campus leadership and the entrepreneurial university: A dynamic capabilities perspective. Academy of Management Perspectives, 30(2), 182-210. https://doi.org/10.5465/amp.2015.0022

Lowry, P. B., \& Gaskin, J. (2014). "Partial least squares (PLS) structural equation modeling (SEM) for building and testing behavioral causal theory: When to choose it and how to use it," IEEE Transactions on Professional Communication, 57(2), 123-146. https://doi.org/10.1109/TPC.2014.2312452

Lubatkin, M. H., Schulze, W. S., Ling, Y., \& Dino, R. N. (2005). The effects of parental altruism on the governance of family-managed firms. Journal of Organizational Behavior, 26, 313-330. https://doi.org/10.1002/job.307

Luque, T. (Edit) (2000). Técnicas de análisis de datos en investigacion e mercados. Madrid: Ediciones Piramide. Retrieved on September 21, 2018, from: https://dialnet.unirioja.es/servlet/libro?codigo=4825

Madison, K., Daspit, J. J., Turner, K., \& Kellermanns, F. W. (2018). Family firm human resource practices: Investigating the effects of professionalization and bifurcation bias on performance. Journal of Business Research, 84, 327-336. https://doi.org/10.1016/j.jbusres.2017. 06.021

Mann, R. J., \& Sager, T. W. (2007). Patents, venture capital, and software start-ups. Research Policy, 36(2), 193-208. doi:10.1016/j.respol. 2006.10.002

Martin, J. A. (2011). Dynamic managerial capabilities and the multibusiness team: the role of episodic teams in executive leadership groups. Organization Science, 22(1), 118-140. https://doi.org/10.1287/orsc.1090.0515

Massa, L., Tucci, C. \& Afuah, A., (2017). A critical assessment of business model research. Academy of Management Annals 11(1), https://doi.org/10.5465/annals.2014.0072

McDonald, M. L., \& Westphal, J. D. (2003). Getting by with the advice of their friends: CEOs' advice networks and firms' strategic responses to poor performance. Administrative Science Quarterly, 48(1), 1-32. https://doi. org/10. 2307/3556617

Miles, R. E., Snow, C. C., Meyer, A. D., \& Coleman, H. J. (1978). Organizational strategy, structure, and process. Academy of management review, 3(3), 546-562. https://doi.org/10.5465/amr.1978.4305755

Nadkarni, S., \& Narayanan, V. K. (2007). Strategic schemas, strategic flexibility, and firm performance: the moderating role of industry clockspeed. Strategic management journal, 28(3), 243-270. https://doi.org/10.1002/ smj.576 
Nicholson, N. (2008). Evolutionary Psychology and Family Business: A New Synthesis for Theory, Research, and Practice. Family Business Review 21(1), 103-118. https://doi.org/10.1111/j.1741-6248.2007.00111.x

Prashantham, S., \& Dhanaraj, C. (2010). The dynamic influence of social capital on the international growth of new ventures. Journal of Management Studies, 47(6), 967-994. https://doi.org/10.1111/j.1467-6486.2009.00904.x

Robert Mitchell, J., Shepherd, D. A., \& Sharfman, M. P. (2011). Erratic strategic decisions: when and why managers are inconsistent in strategic decision making. Strategic Management Journal, 32(7), 683-704. https://doi. org/10.1002/smj.905

Rodenbach, M., \& Brettel, M. (2012). CEO experience as micro-level origin of dynamic capabilities. Management Decision, 50(4), 611-634. https://doi.org/ 10.1108/00251741211220174

Rosenbloom, R. S. (2000). Leadership, capabilities, and technological change: The transformation of NCR in the electronic era. Strategic Management Journal, 21(10-11), 1083-1103. https://doi.org/10.1002/10970266(200010/11)21:10/11 <1083::AID-SMJ127>3.0.CO;2-4

Rothaermel, F. T., \& Hess, A. M. (2007). Building dynamic capabilities: Innovation driven by individual-, firm-, and network-level effects. Organization Science, 18(6), 898-921. https://doi.org/10.1287/orsc.1070.0291

Rutherford, M.W., Kuratko, D.F., \& Holt, D.T. (2008). Examining the Link Between "Familiness" and Performance: Can the F-PEC Untangle the Family Business Theory Jungle? Entrepreneurship Theory and Practice: 1089-1110. https://doi.org/10.1111/j.1540-6520.2008.00275.x

Sacristán-Navarro, M., Gómez-Ansón, S., \& Cabeza-García, L. (2011). Family ownership and control, the presence of other large shareholders, and firm performance: Further evidence. Family Business Review, 24(1), 71-93. https://doi.org/10.1177/0894486510396705

Salas, E., Rosen, M. A., \& DiazGranados, D. (2010). Expertise-based intuition and decision making in organizations. Journal of management, 36(4), 941-973. https://doi.org/10.1177/0149206309350084

Salvato, C. (2003). The Role of Micro Strategies in the Engineering of Firm Evolution. Journal of Management Studies, 40(1), 83-108 https://doi.org/10. 1111/1467-6486.t01-2-00005

Salvato, C., \& Vassolo, R. (2018). The sources of dynamism in dynamic capabilities. Strategic Management Journal, 39(6), 1728-1752. https: //doi.org/10.1002/smj.2703

Schilke, O. (2014). On the contingent value of dynamic capabilities for competitive advantage: The nonlinear moderating effect of environmental dynamism. Strategic Management Journal, 35(2), 179-203. https://doi. org/10. 1002/smj.2099

Schulze, W. S., Lubatkin, M. H., \& Dino, R. N. (2003). Toward a theory of agency and altruism in family firms. Journal of Business Venturing, 18, 473-490. https://doi.org/10.1016/S0883-9026(03)00054-5

Schulze, W., Lubatkin, M., Dino, R., \& Bochholtz, A. (2001). Agency Relationships in Family Firms: Theory and Evidence. Organization Science, 12(2), 99-116. https://doi.org/10.1287/orsc.12.2.99.10114

Schumpeter, J. A. (1934). The theory of economic development: An inquiry into profits, capital, credit, interest, and the business cycle. Harvard University Press, Cambridge, MA. Retrieved on January 15, 2019, from: https:// mpra.ub.uni-muenchen.de/69883/1/MPRA_paper_69883.pdf

Sharma, P., Chrisman, J. J., \& Chua, J. H. (1997). Strategic management of the family business: Past research and future challenges. Family Business Review, 10(1), 1-35. https://doi.org/10.1111/j.1741-6248.1997.00001.x

Sirmon, D. G., \& Hitt, M. A. (2003). Managing resources: Linking unique resources, management, and wealth creation in family firms. Entrepreneurship theory and practice, 27(4), 339-358. https://doi.org/10.1111/15408520.t01-1-00013

Sirmon, D. G., \& Hitt, M. A. (2009). Contingencies within dynamic managerial capabilities: interdependent effects of resource investment and deployment on firm performance. Strategic Management Journal, 30(13), 13751394. https:// doi.org/10.1002/smj.791

Stewart, A., \& Hitt, M. A. (2012). Why can't a family business be more like a nonfamily business? Modes of professionalization in family firms. Family Business Review, 25, 58-86. https://doi.org/10.1177/ 0894486511421665 


\section{S. S. Guajardo Treviño, et al. / Contaduría y Administración 65(3), 2020, 1-28}

http://dx.doi.org/10.22201/fca.24488410e.2020.2132

Subramaniam, M., \& Youndt, M. A. (2005). The influence of intellectual capital on the types of innovative capabilities. Academy of Management Journal, 48(3), 450-463. https://doi.org/10.5465/amj.2005.17407911

Tabachnick, B. G., \& Fidell, L. S. (2007). Experimental designs using ANOVA. Thomson/Brooks/Cole. Retrieved on January 15, 2019, from: https://openlibrary.org/books/OL17159351M/Experimental_designs_using_ANOVA

Tabor, W., Chrisman, J. J., Madison, K., \& Vardaman, J. M. (2018). Nonfamily members in family firms: A review and future research agenda. Family Business Review, 0894486517734683. https://doi.org/10.1177/08944865177 34683

Teece, D. J. (2000). Strategies for managing knowledge assets: the role of firm structure and industrial context. Long range planning, 33(1), 35-54. https://doi. org/10.1016/S0024-6301(99)00117-X

Teece, D. J. (2007). Explicating dynamic capabilities: the nature and microfoundations of (sustainable) enterprise performance. Strategic management journal, 28(13), 1319-1350. https://doi.org/10.1002/smj.640

Teece, D. J. (2009). Dynamic capabilities and strategic management: organizing for innovation and growth. Oxford University Press. doi:10.1111/j.1467-9310.2011.00638.x

Teece, D. J. (2016). Dynamic capabilities and entrepreneurial management in large organizations: Toward a theory of the (entrepreneurial) firm. European Economic Review, 86, 202-216. https://doi.org/10.1016 /j.euroecorev.2015.11.006

Teece, D.J. (2018). Business models and dynamic capabilities. Long Range Planning 51, 40-49. https://doi. org/10.1016/j.1rp.2017.06.007

Teece, D. J., Pisano, G., \& Shuen, A. (1997). Dynamic capabilities and strategic management. Strategic Management Journal, 18(7), 509-533. https://doi.org/ 10.1002/(SICI)1097-0266(199708)18:7<509::AID-SMJ882>3.0.CO;2-Z

Tripsas, M., \& Gavetti, G. (2000). Capabilities, cognition, and inertia: Evidence from digital imaging. Strategic management journal, 21(10-11), 1147-1161. https://doi.org/10.1002/1097-0266(200010/11)21:10/11<1147::AIDSMJ128>3.0.CO;2-R

Wang, C. L., \& Ahmed, P. K. (2007). Dynamic capabilities: A review and research agenda. International journal of management reviews, 9(1), 31-51. https://doi.org/10.1111/j.1468-2370.2007.00201.x

Weston, R., \& Gore Jr, P. A. (2006). A brief guide to structural equation modeling. The counseling psychologist, 34(5), 719-751. https://doi.org/10. 1177/0011000006286345

Wilden, R., Gudergan, S. P., Nielsen, B. B., \& Lings, I. (2013). Dynamic capabilities and performance: strategy, structure and environment. Long Range Planning, 46(1), 72-96. https://doi.org/10.1016/j.lrp.2012.12.001

Winter, S.G. (2003). Understanding dynamic capabilities. Strategic Management Journal, 24, 991-995. https://doi. org/10.1002/smj.318

Zahra, S. (2005). Entrepreneurial Risk Taking in Family Firms. Family Business Review, 18(1), 23-40. https://doi. org/10.1111/j.1741-6248.2005.00028.x

Zahra, S. A., Neubaum, D. O., \& Larrañeta, B. (2007). Knowledge sharing and technological capabilities: The moderating role of family involvement. Journal of Business Research, 60(10), 1070-1079. https://doi. org/10.1016/j.jbusres.2006. 12.014

Zhang, M. J. (2007). Is support for top managers' dynamic capabilities, environmental dynamism, and firm performance: an empirical investigation. Journal of Business and Management, 13(1), 57. Retrieved on January 15, 2019, from: https://pdfs.semanticscholar.org/0234/a3d277df94f43e7718344680da64f 4f23c29.pdf

Zhang, Y., \& Rajagopalan, N. (2010). Once an outsider, always an outsider? CEO origin, strategic change, and firm performance. Strategic Management Journal, 31(3), 334. https://doi.org/10.1002/smj.812 